\title{
Life on the edge: Coral reef fishes exhibit strong responses to a habitat boundary
}

\author{
Katie Sambrook $^{1,2, *}$, Geoffrey P. Jones ${ }^{1,2}$, Mary C. Bonin ${ }^{1,2}$ \\ ${ }^{1}$ Marine Biology and Aquaculture, College of Science \& Engineering, and ${ }^{2}$ ARC Centre of Excellence for Coral Reef Studies, \\ James Cook University, Townsville, Queensland 4811, Australia
}

\begin{abstract}
Habitat edges commonly support discrete communities compared to adjoining habitats in response to unique boundary conditions. Coral reefs are often adjacent to other habitats, e.g. sand or seagrass meadows, but little is known about how reef-associated organisms respond to the presence of edges. Here, we examined fish communities and benthic assemblages at varying distance from a coral reef-sand edge. At 25 sites, $30 \mathrm{~m}$ transects were placed at 5 locations: 1 along the edge and at $5 \mathrm{~m}$ and $10 \mathrm{~m}$ away from the edge into reef and sand habitats. Counts were made of 51 fish species and benthic composition surveyed. The fish community along the edge was substantially different to communities only $5 \mathrm{~m}$ into the sand and reef habitats. Overall, $61 \%$ of the 51 fish species appeared to respond to the edge, with $43 \%$ significantly higher or lower in abundance along the edge compared to other locations. Twelve species showed positive edge responses, including the wrasse Thalassoma lunare, which was 30 times more abundant along the edge compared to $10 \mathrm{~m}$ into the reef. Ten species exhibited negative edge responses, including the damselfish Pomacentrus moluccensis, which was 7 times more abundant $10 \mathrm{~m}$ into the reef compared to the edge. Feeding ecology appears to influence edge-related distribution patterns, with carnivores and omnivores dominating the edges and planktivores more abundant into the reef. These findings suggest that habitat edges may play an important role in structuring coral reef fish communities. Future research should focus on experimental approaches to identify the underlying mechanisms driving edge responses.
\end{abstract}

KEY WORDS: Edge effects · Habitat fragmentation · Landscape ecology · Seascape ecology · Coral reef fish · Ontogenetic shifts

\section{INTRODUCTION}

Understanding the spatial distribution of organisms is an enduring goal in ecology (Gaston 2000, Krebs 2006). Many ecological studies have concentrated on species distributions within a single habitat type, yet most environments are heterogeneous and composed of a mosaic of habitats (Turner 2005, Boström et al. 2011, Davis et al. 2014). Habitat edges are therefore a ubiquitous feature of terrestrial and aquatic landscapes, and are defined as the interface between 2 adjoining habitat types (e.g. forest and meadow, seagrass and sand) (Murcia 1995, Fagan et al. 1999, Strayer et al. 2003). This boundary between contiguous habitats creates abiotic conditions (e.g. light, exposure, temperature) that are distinct from either of the adjacent habitats (Ewers \& Didham 2006). Edges also bring species that are associated with adjacent habitats into contact with each other, which can produce novel biotic conditions and species interactions (Fagan et al. 1999). Because species may exhibit a range of responses to these altered abiotic and biotic conditions, unique community assemblages often occur along habitat edges (Fagan et al. 1999, Fletcher et al. 2007).

Habitat edges are hypothesised to influence spatial distribution patterns through 4 principal mechanisms (Ries et al. 2004). First, edges can modify the flow of 
organisms, materials, and resources. For example, a reduction in wind-shear stress along an edge between a meadow and woodland can affect the dispersal distance of seeds into the forest (Cadenasso \& Pickett 2001). Edges can also provide motile organisms with access to spatially separated resources (Ries et al. 2004), which can sometimes be beneficial for species living along habitat edges. For example, nesting passerine birds select sites close to edges, seeking refuge within the forest habitat and foraging in neighbouring open pastures (Gates \& Gysel 1978). Moreover, the distribution of an organism is also a reflection of its resource requirements, and hence, individuals map onto gradients of resource availability, which may differ along edges (Ries et al. 2004). Finally, species interactions may influence edgerelated distribution patterns (Fagan et al. 1999). Elevated predation risk is often cited as a major attribute of edge habitat (Gates \& Gysel 1978, Andrén \& Angelstam 1988), but competition and parasitism may also be important factors underpinning edge responses (Ries et al. 2004, Fletcher et al. 2007). The magnitude of an edge effect, and therefore how individual species respond, can vary with distance from a habitat edge (e.g. Didham \& Lawton 1999, Hylander 2005). Some organisms show a strong directional response to the presence of edge habitat, whereas others exhibit a subtler gradient of change with distance from the edge.

Interest in understanding species' responses to habitat edges is increasingly motivated by concerns about the ecological consequences of habitat loss and fragmentation, which typically increase the amount of edge habitat in natural landscapes (Laurance \& Yensen 1991, Fletcher et al. 2007). In terrestrial landscapes, increased edge habitat has been implicated in biodiversity losses, population declines, changes to community composition, and altered ecosystem functioning (Saunders et al. 1991, Cushman 2006, Laurance et al. 2007, Haddad et al. 2015). For example, fragmentation has exposed forest-dwelling birds to habitat edges where they are more vulnerable to novel species interactions, including increased predation, competition, and brood parasitism (Murcia 1995, Donovan et al. 1997, Harrison \& Bruna 1999).

Habitat loss and fragmentation are also growing concerns in coastal marine ecosystems (Gray 1997, Eggleston et al. 1998, Connolly \& Hindell 2006), where major drivers include coastal development, destructive fishing practices, and severe storms (Hovel \& Lipcius 2001, Boström et al. 2006, Orth et al. 2006, Airoldi \& Beck 2007). However, efforts to understand the impacts of habitat loss on marine taxa have predominantly concentrated on within-habitat patterns rather than processes operating across the interface of different habitat types. Coastal marine seascapes are naturally composed of a mosaic of different habitat patches, making shallow water habitats ideal systems in which to study edge effects. Yet research into edge effects in the marine environment has lagged behind terrestrial studies (Smith et al. 2008).

Of the few edge effects studies that have been conducted within marine systems, most focus on subtidal seagrass habitats adjacent to soft-sediment communities (e.g. Bologna \& Heck 2002, Smith et al. 2008). Almost nothing is known about edge effects in other marine habitats (e.g. coral reefs, mangroves, rocky reefs; but see Langlois et al. 2005, 2006). Moreover, whilst edge effects in fish and invertebrate taxa have been explored in seagrass systems, methods to collect such data frequently vary between studies, or taxa are grouped, which makes it challenging to identify consistent patterns associated with the presence of edge habitat. Furthermore, only a few studies to date have examined how marine communities change with increasing distance from the habitat edge (e.g. Tanner 2005). For fish, body size, stage of ontogeny, and trophic group appear to contribute towards edge effects in seagrass beds. Predatory fish or large-bodied herbivores have been recorded in higher abundances along edges (Dorenbosch et al. 2005, Smith et al. 2011), whereas small-bodied fish and juveniles appear to be more abundant in patch interiors (Shulman 1985, Maciá \& Robinson 2005). These observations suggest that ontogenetic stage, trophic group, and body size may be important considerations in evaluating how individual species respond to edge habitat in the marine environment. However, to date, studies into edge effects in marine habitats other than seagrass beds are scarce.

Coral reefs adjacent to sand are a common feature of tropical marine seascapes, yet it is unknown how coral reef fish communities respond to the presence of this type of edge. Therefore, this study will use an observational approach to provide the first description of distribution patterns of coral reef fishes, as well as their underlying benthic habitat, with distance from the reef-sand edge. The following key questions will be addressed to provide a basis for future experimental research on edge effects in coral reef fish communities: (1) Does the composition of the reef fish community change along the edge compared to 5 or $10 \mathrm{~m}$ into adjacent habitat patches, and is this associated with changes in benthic habitat structure? (2) Is there evidence that feeding ecology 
influences edge-related distribution patterns (e.g. are predators more abundant along the habitat edge)? (3) Given that edge responses are likely to be species-specific, what proportion of the reef fish community responds positively, negatively, or neutrally to the presence of edge habitat? (4) Does ontogenetic stage influence edge effects (i.e. do juvenile coral reef fishes avoid the edge in favour of more complex habitat)?

\section{MATERIALS AND METHODS}

\section{Study region and sampling design}

The study was conducted in Kavieng lagoon, New Ireland, Papua New Guinea $\left(2^{\circ} 34^{\prime} \mathrm{S}, 150^{\circ} 48^{\prime} \mathrm{E}\right)$ over a 2 wk period between March and April 2015. The region is relatively undeveloped and characterised by a mosaic seascape of coral reefs, mangroves, seagrass, and sandy soft-sediment habitats across an area of $\sim 380 \mathrm{~km}^{2}$. Twenty-five survey sites were identified on the leeward sides of continuous sections of fringing reefs in the Kavieng lagoon. In this study, the primary criterion for site selection was an abrupt transition from coral reef into sandy soft-sediment that provided a clear edge between the 2 habitat types. All sites were separated by $\geq 50 \mathrm{~m}$, and were haphazardly interspersed across the lagoon. Surveys were conducted on SCUBA between 09:00 and 16:00 h. To examine changes to fish communities and benthic habitat across the coral reef-sand edge, surveys were conducted at 5 locations: along the edge itself and also at $5 \mathrm{~m}$ and $10 \mathrm{~m}$ from the edge into each adjacent habitat type. At each site, five $30 \mathrm{~m}$ transects were laid parallel to the edge, with the edge transect laid first along the contour of the reef edge, and the 4 remaining transects (Reef $5 \mathrm{~m}$, Reef $10 \mathrm{~m}$, Sand $5 \mathrm{~m}$, and Sand $10 \mathrm{~m}$ ) following the same contours as the edge transect. Because there was often a gradient in depth across these 5 transects, water depth was also measured at the start and end of each transect to allow us to determine the potential of this abiotic factor to influence fish and benthic assemblages irrespective of proximity to edge.

The fish communities at each distance from the reef-sand edge were surveyed by a single observer (K.S.) using underwater visual census techniques on SCUBA. A total of 51 fish species from 13 coral reef families were selected, as these were the most common species observed at the study sites. Accuracy of species identification was validated with photographs taken in situ during a pilot study. The 51 fish species (Table S1 in the Supplement at www.intres.com/articles/suppl/m561p203_supp.pdf) were counted along $30 \times 2 \mathrm{~m}$ belts at each of the 5 locations (edge, and 5 and $10 \mathrm{~m}$ into the sand and reef habitats) at each site. After transect placement, divers left the area for $5 \mathrm{~min}$ prior to the fish surveys to minimise disturbance. Larger and more mobile fishes were counted along each transect first, followed by smaller, sedentary fishes. Care was taken to avoid multiple counting of more mobile species that moved in and out of the belt transect during the survey. For the edge transect, the $2 \mathrm{~m}$ belt included $1 \mathrm{~m}$ of sand and $1 \mathrm{~m}$ of reef habitat. For 49 species, the counts did not discriminate between adults or juveniles, because juveniles were either rarely observed or difficult to distinguish from adults. However for 2 of the 51 species, Halichoeres melanurus and Thalassoma lunare, both juveniles and adults were abundant and easily identifiable. Therefore, adults and juveniles of these 2 wrasse species were counted to explore the potential for differences in edge responses with ontogenetic stage.

Variation in benthic habitat composition across the coral reef-sand edge was quantified using a line point transect approach by identifying the benthos below 60 random points along each of the 5 transects at each site. Scleractinian corals were identified to genus level. An additional 11 benthic categories were recorded along each transect: Tubipora, Millepora, gorgonians, soft corals, sponges, macroalgae, coralline algae, turf algae/rock, rubble, soft sediment (e.g. sand, silt, and mud), or other benthic organisms (e.g. zoanthids and corallimorphs). Points were converted to proportions prior to analysis.

\section{Data analyses}

Differences in the composition of the fish community with distance from the habitat edge were explored using non-metric multidimensional scaling (nMDS) based on a Bray-Curtis resemblance matrix using $\log (x+1)$ transformed data (Primer-E v. 6). $\log (x+1)$ transformed data are considered appropriate for multivariate analyses, as the transformation down-weights the influence of a few highly abundant species to focus on examining community-level patterns (Clarke \& Warwick 2001). Hierarchical clustering based on group-average mean linkage (Clarke 1993, Clarke \& Warwick 2001) was used to identify communities with $40 \%$ similarity. Analysis of similarities (ANOSIM) derived from the Bray-Curtis resemblance matrix (max. permutations: 9999) tested for 
significant differences in the fish communities between the 5 locations (i.e. the edge, and 5 and $10 \mathrm{~m}$ from the edge into both sand and reef habitat). The similarity percentages routine (SIMPER) was then used to identify the fish species contributing to differences between and similarities within each location. The same analyses were used to examine how the overall benthic assemblage and live hard coral composition differed across the reef-sand edge, but were based on untransformed proportion data (Clarke 1993). For the overall benthic assemblage, the 11 benthic categories (Tubipora, Millepora, gorgonians, soft corals, sponges, macroalgae, coralline algae, turf algae/rock, rubble, soft sediment, or other benthic organisms) and coral genus were used in the analysis. Changes in the live hard coral composition were examined at the genus level and only compared between the edge and 5 and $10 \mathrm{~m}$ into the reef.

Depth varied considerably across edge transects (mean: $7.4 \mathrm{~m}$, min.: $4.1 \mathrm{~m}$, max.: $10.5 \mathrm{~m}$ ); however, sampling occurred across a reef slope, and consequently there was a depth gradient, with transects laid $10 \mathrm{~m}$ into the reef (mean: $3.4 \mathrm{~m}$, min.: $1.0 \mathrm{~m}$, max.: $6.5 \mathrm{~m}$ ) consistently shallower than transects laid $10 \mathrm{~m}$ into sand (mean: $8.6 \mathrm{~m}$, min.: $3.5 \mathrm{~m}$, max.: $12.4 \mathrm{~m}$ ). Because depth varied consistently across the gradient, we evaluated whether it influenced the fish community irrespective of edge location. This was achieved by grouping transects into 3 depth ranges irrespective of their location from the edge $(0-4 \mathrm{~m}$, $4.1-8 \mathrm{~m}$, and $>8 \mathrm{~m}$ ) and using 1-way ANOSIM to test for differences in the fish community across depth categories. Because depth had little influence on fish community composition (global $\mathrm{R}=0.123, \mathrm{p}=0.400$ ), we assumed that any differences in fish communities across locations were due to proximity to edge rather than depth, and depth was not considered a factor in further analyses.

To compare whether the total amount of live hard coral differed between the edge and reef transects, a 1-way ANOVA using arcsin-transformed percent data was conducted, followed by Tukey's post hoc test. Coral genus richness between the edge and reef transects was compared with a 1-way ANOVA on untransformed data using the number of coral genera counted per transect. Differences in fish species richness with distance from the edge was analysed using a 1-way ANOVA on untransformed data, followed by a Tukey post hoc comparison. Preliminary residuals analysis of fish count data revealed nonnormal distributions due to large differences in densities between sand and edge/reef transects. Transformations did not improve normality; therefore, non-parametric Kruskal-Wallis tests were used to compare total fish abundance, as well as the abundance of individual species, across the edge. These were followed by post hoc Mann-Whitney $U$-tests to identify which locations differed. Because the species-level analyses involved multiple comparisons between groups, Bonferroni corrections were applied to make significance testing more conservative (adjusted $\mathrm{p}=0.005$ ).

To examine the influence of feeding ecology on edge-related distribution patterns, the 51 species were assigned to 1 of 5 feeding guilds (i.e. carnivores, corallivores, herbivores, omnivores, and planktivores) based on published information on their feeding habits (Table S1 in the Supplement). In this study, carnivores were defined as species that primarily consume macroinvertebrates (e.g. crustaceans, echinoderms, gastropods) and/or fish. Omnivores were classified as species that consume both plant and animal material, and the category herbivore included species that primarily eat organic plant matter and/or detritus. Differences in the mean abundance of fish in each feeding guild were compared across the edge locations with 1-way ANOVAs, followed by Tukey's post hoc tests. Residuals analyses and Levene's tests were used to check assumptions, and abundance data for each feeding guild was square root-transformed to homogenise variances of residuals across groups prior to analyses.

Finally, contingency analyses were used to test whether ontogenetic stage influenced distributions across the edge for 2 coral reef fish species. Two-way tables were constructed by cross-classifying counts based on: ontogenetic stage (i.e. juvenile or adult) and location across edge (i.e. $10 \mathrm{~m}$ sand, $5 \mathrm{~m}$ sand, edge, $5 \mathrm{~m}$ reef, $10 \mathrm{~m}$ reef). Prior to analyses, tables were checked to ensure that no more than $20 \%$ of cell values were below 5 . A chi-squared statistic was used to test the null hypothesis that distribution across the edge was independent of ontogenetic stage, and standardised Pearson's residuals were used to interpret lack of independence.

\section{RESULTS}

\section{Benthic assemblage structure across habitat edge}

Benthic composition changed significantly with distance from the habitat edge (ANOSIM: global $\mathrm{R}=$ $0.562, \mathrm{p}<0.01)$. Looking at the multivariate space (Fig. 1), benthic transects along the habitat edge clustered together and were characterised by a mix- 

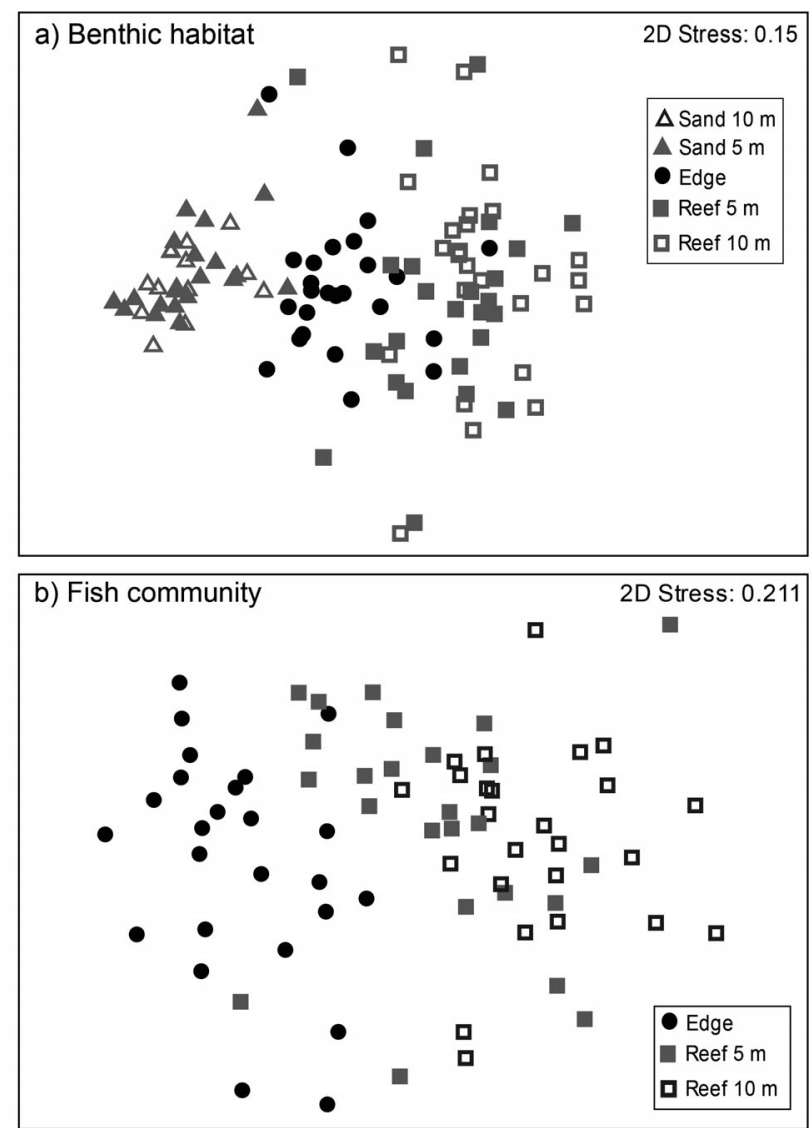

Fig. 1. Variation in the structure of (a) benthic habitat and (b) coral reef fish communities with distance from the coral reef-sand edge. Benthic habitat and fish communities along the edge were distinct from those only 5 to $10 \mathrm{~m}$ away from the edge into adjacent sand and reef habitats. Stress values in non-metric multidimensional scaling (nMDS) plots indicate that 2 dimensions were adequate to accurately display relationships between points in multivariate space

ture of soft sediment, Porites rubble, and turf algae/ rock (Fig. 1a, Table 1). They were significantly different in their composition to both sand locations $(5 \mathrm{~m}$ into sand: $\mathrm{R}=0.647, \mathrm{p}<0.001 ; 10 \mathrm{~m}$ into sand: $\mathrm{R}=$ $0.78, \mathrm{p}<0.001)$, which was largely due to the substantially higher percentage cover of soft sediment 5 to $10 \mathrm{~m}$ from the edge, $75 \%$ and $83 \%$ respectively, relative to $25 \%$ cover along the edge. Edge transects were also significantly different in composition to transects both $5 \mathrm{~m}(\mathrm{R}=0.204, \mathrm{p}<0.001)$ and $10 \mathrm{~m}$ away from the edge into the reef habitat $(\mathrm{R}=0.352$, $\mathrm{p}<0.001)$. The reef benthic composition $10 \mathrm{~m}$ and $5 \mathrm{~m}$ away from the edge was dominated by Porites, soft corals, rubble, and turf algae/rock (Table 1). Differences between the edge and the reef benthic assemblages were driven by more soft sediment recorded along the edge and more Porites into the reef habitat.

Table 1. SIMPER analysis showing average \% similarity of benthic assemblage and fish community across 25 replicate transects at each of the 5 locations relative to habitat edge. Benthic habitat categories and fish species contributing most to similarities among transects for each location are listed, along with their \% contribution at that location

\begin{tabular}{|c|c|c|c|c|c|c|}
\hline \multirow{2}{*}{ Location } & \multicolumn{3}{|c|}{ Benthic assemblage } & \multirow[b]{2}{*}{$\begin{array}{c}\text { \% Similarity } \\
\text { among } \\
\text { transects }\end{array}$} & \multicolumn{2}{|l|}{ - Fish community } \\
\hline & $\begin{array}{l}\text { \% Similarity } \\
\text { among } \\
\text { transects }\end{array}$ & $\begin{array}{c}\text { Characteristic } \\
\text { benthic } \\
\text { categories }\end{array}$ & $\begin{array}{c}\% \text { Contribution } \\
\text { to } \\
\text { assemblage }\end{array}$ & & $\begin{array}{l}\text { Characteristic } \\
\text { fish } \\
\text { categories }\end{array}$ & $\begin{array}{c}\% \text { Contribution } \\
\text { to } \\
\text { assemblage }\end{array}$ \\
\hline \multirow[t]{3}{*}{ Sand $10 \mathrm{~m}$} & 75.87 & Soft sediment & 96.15 & 6.85 & Pomacentrus coelestis & 35.80 \\
\hline & & & & & Scolopsis lineata & 24.97 \\
\hline & & & & & Dascyllus reticulatus & 7.71 \\
\hline \multirow[t]{3}{*}{ Sand $5 \mathrm{~m}$} & 68.61 & Soft sediment & 90.26 & 10.94 & D. reticulatus & 13.76 \\
\hline & & & & & Scolopsis ciliata & 11.57 \\
\hline & & & & & Halichoeres melanurus & 11.44 \\
\hline \multirow[t]{4}{*}{ Edge } & 47.33 & Soft sediment & 38.24 & 47.48 & Pomacentrus amboinensis & 11.54 \\
\hline & & Porites & 13.24 & & H. melanurus & 10.48 \\
\hline & & Rubble & 12.29 & & Chrysiptera talboti & 10.30 \\
\hline & & Turf algae/rock & 10.72 & & & \\
\hline \multirow[t]{3}{*}{ Reef $5 \mathrm{~m}$} & 38.20 & Porites & 32.02 & 46.64 & Pomacentrus moluccensis & 12.31 \\
\hline & & Soft corals & 13.25 & & Amblyglyphidodon curacao & 11.53 \\
\hline & & Turf algae/rock & 10.87 & & C. talboti & 10.99 \\
\hline \multirow[t]{3}{*}{ Reef $10 \mathrm{~m}$} & 37.69 & Porites & 36.44 & 51.77 & P. moluccensis & 19.48 \\
\hline & & Soft corals & 11.29 & & A. curacao & 14.47 \\
\hline & & Rubble & 10.74 & & Pomacentrus lepidogenys & 10.86 \\
\hline
\end{tabular}


Although the composition of the benthic assemblage changed with distance from edge, there was no difference in the composition of the hard coral community between the edge and 5 or $10 \mathrm{~m}$ into the reef (ANOSIM: global $\mathrm{R}=0.003, \mathrm{p}=0.4$ ), and coral genus richness was also similar across the 3 locations $\left(F_{2,72}=\right.$ 3.017, $p=0.055$; Fig. 2a). However, live hard coral cover was significantly lower along the edge compared to both reef locations $\left(F_{2,72}=13.944, \mathrm{p}<0.001\right.$; Fig. 2b).

\section{Fish community responses to habitat edge}

During the study, a total of 14732 individuals from 51 fish species were counted across 125 transects. Total fish abundance along the edge was similar to 5 and $10 \mathrm{~m}$ into the reef habitat, with approximately 150-200 fish per $30 \mathrm{~m}^{2}$ (Fig. 2c). Fish abundance along reef and edge transects was approximately 9 times higher compared to sand transects (Fig. 2c). The edge had the highest species richness of all 5 locations, with 21 fish species on average, significantly different to all other locations, except $5 \mathrm{~m}$ into the reef $\left(F_{4,120}=73.376, \mathrm{p}<0.001\right)$. Coral reef fish


Fig. 2. Mean $( \pm \mathrm{SE})$ scleractinian coral (a) genus richness and (b) percent cover with distance from edge, and fish (c) species richness and (d) abundance. Percent coral cover was higher into the reef compared to the edge. Fish species richness was lowest in the sand habitat and highest along the edge, with the fish community $10 \mathrm{~m}$ into the reef having lower fish species richness than the edge. Fish abundance was lowest on the sand, but did not differ between the edge and reef habitat. Letters above bars denote similar groups based on post hoc tests species richness along the edge was almost 8 times higher than $10 \mathrm{~m}$ onto the sand, and 1.4 times higher than $10 \mathrm{~m}$ into the reef (Fig. 2d).

Multivariate analyses revealed that the composition of the fish community along the habitat edge was substantially different to the fish community only 5 to $10 \mathrm{~m}$ into both the sand and reef habitats (ANOSIM: global $\mathrm{R}=0.384, \mathrm{p}<0.001$ ). An initial nMDS plot revealed that fish communities in the sandy habitat were so highly dissimilar in their composition compared to those along the edge and on the reef that when all 125 transects were plotted together in nMDS space, the 75 edge and reef transects formed a tight, overlapping cluster (Fig. S1 in the Supplement at www.int-res.com/articles/suppl/m561p203_supp.pdf). Fish communities in the sand were highly variable (i.e. only $6-10 \%$ similarity among transects), but were generally characterised by Pomacentrus coelestis, Dascyllus reticulatus, Halichoeres melanurus, Scolopsis lineata, and Scolopsis ciliata (Table 1). When only transects from the edge and reef habitat were plotted in nMDS space (Fig. 1b), it became clear that fish community composition along the habitat edge was also distinct from that of fish communities only $5 \mathrm{~m}(\mathrm{R}=0.416, \mathrm{p}<0.001)$ and $10 \mathrm{~m}(\mathrm{R}=$ $0.763, \mathrm{p}<0.001)$ into the reef. Cluster analysis revealed that $92 \%$ of the transects along the edge were contained within one $40 \%$ similarity cluster, which indicated that fish communities along the edge were highly similar in their composition despite sampling edges across a wide range of locations and depths.

SIMPER analysis revealed that differences in edge communities from those 5-10 $\mathrm{m}$ away were due to overall shifts in community composition, rather than variation in the abundance of 1 or 2 species. There was a high degree of dissimilarity $(61.8 \%)$ in the compositions of the fish communities along the edge and $5 \mathrm{~m}$ into the reef, with 14 species contributing to $50 \%$ of this dissimilarity. Likewise, the fish community $10 \mathrm{~m}$ into the reef was also highly dissimilar to the edge $(68.6 \%)$, with 13 species contributing to these differences in community composition. 
In addition to revealing the degree of dissimilarity between fish communities with increasing distance from the habitat edge, SIMPER also provided insight into the species that characterised each location. Six species accounted for $50 \%$ of the similarity among transects surveyed along the edge habitat: Pomacentrus amboinensis, Chrysiptera talboti, Amblyglyphidodon curacao, Pomacentrus nigromanus, H. melanurus, and $S$. ciliata (Table 1). The reef transects $5 \mathrm{~m}$ away from the edge were characterised by the damselfishes Pomacentrus moluccensis, A. curacao, C. talboti, Chromis atripes, and wrasse of the genus Labroides. Diagnostic species for the reef transects $10 \mathrm{~m}$ away from the edge were $P$. moluccensis, Pomacentrus lepidogenys, and A. curacao, which together accounted for over $50 \%$ of the similarity observed between the $10 \mathrm{~m}$ reef transects (Table 1 ).

\section{Edge responses across coral reef fish feeding guilds}

Grouping the 51 species based on their feeding ecology revealed that edge responses were highly consistent across feeding guilds (Fig. 3). Carnivores and omnivores were both significantly more abundant along the edge compared to all other locations (carnivores: $F_{4,120}=54.636, \mathrm{p}<0.001$; omnivores: $\left.F_{4,120}=57.688, \mathrm{p}<0.001\right)$. With an average of 38 individuals per $\mathrm{m}^{2}$ along the edge, carnivores were 2 and
3 times more abundant on the edge compared to 5 or $10 \mathrm{~m}$ into the reef (Fig. 3a). Similarly, omnivores were also twice as abundant along the edge compared to $5 \mathrm{~m}$ into the reef and 3 times more abundant along the edge than $10 \mathrm{~m}$ into the reef (Fig. 3b). In contrast, both planktivores and corallivores were less abundant along the edge compared to $10 \mathrm{~m}$ into the reef (Fig. 3c,d). For planktivores, this decrease in abundance along the edge was significant $\left(F_{4,120}=67.720\right.$, $\mathrm{p}<0.001)$, with almost 2.5 times less fish counted along the edge than $10 \mathrm{~m}$ into the reef (Fig. 3c). Herbivorous fishes were more abundant at locations containing reef habitat compared to the soft-sediment habitat, but there was no significant difference between the edge and reef locations (Fig. 3e).

\section{Species-specific responses to habitat edge}

The 51 fish species surveyed showed considerable variation in their responses to habitat edges, with some species exhibiting strong positive and negative responses, while others had neutral responses to the presence of edge habitat (Fig. 4). Nineteen species (37\%) appeared to exhibit a positive edge response, and for 12 of these species (i.e. $24 \%$ of the community), abundance was significantly higher along the edge compared to other locations (Fig. 4a-d). For example, the damselfish $P$. amboinensis was at least 10 times more abundant along the edge compared to
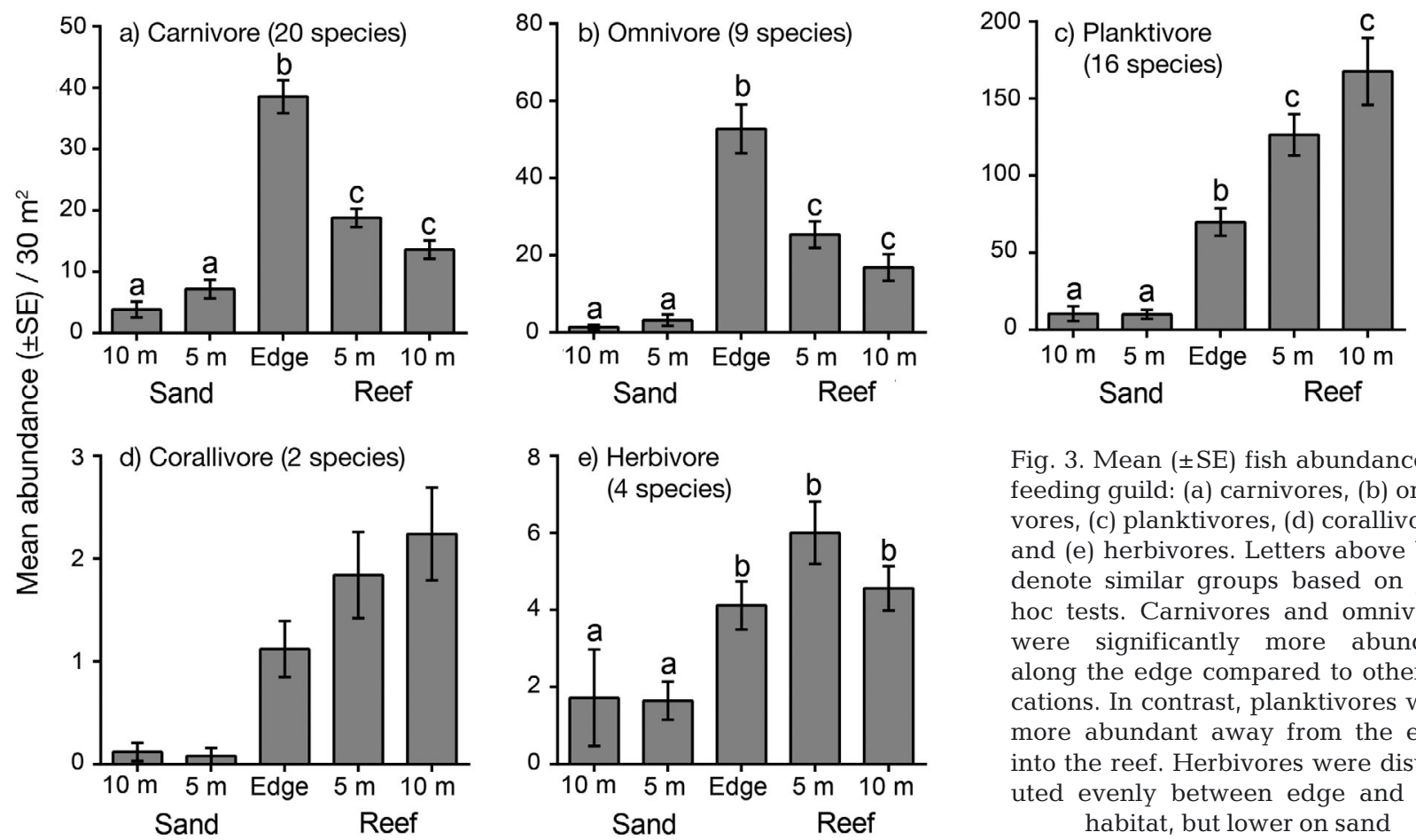

Fig. 3. Mean $( \pm \mathrm{SE})$ fish abundance by feeding guild: (a) carnivores, (b) omnivores, (c) planktivores, (d) corallivores, and (e) herbivores. Letters above bars denote similar groups based on post hoc tests. Carnivores and omnivores were significantly more abundant along the edge compared to other locations. In contrast, planktivores were more abundant away from the edge into the reef. Herbivores were distributed evenly between edge and reef habitat, but lower on sand 

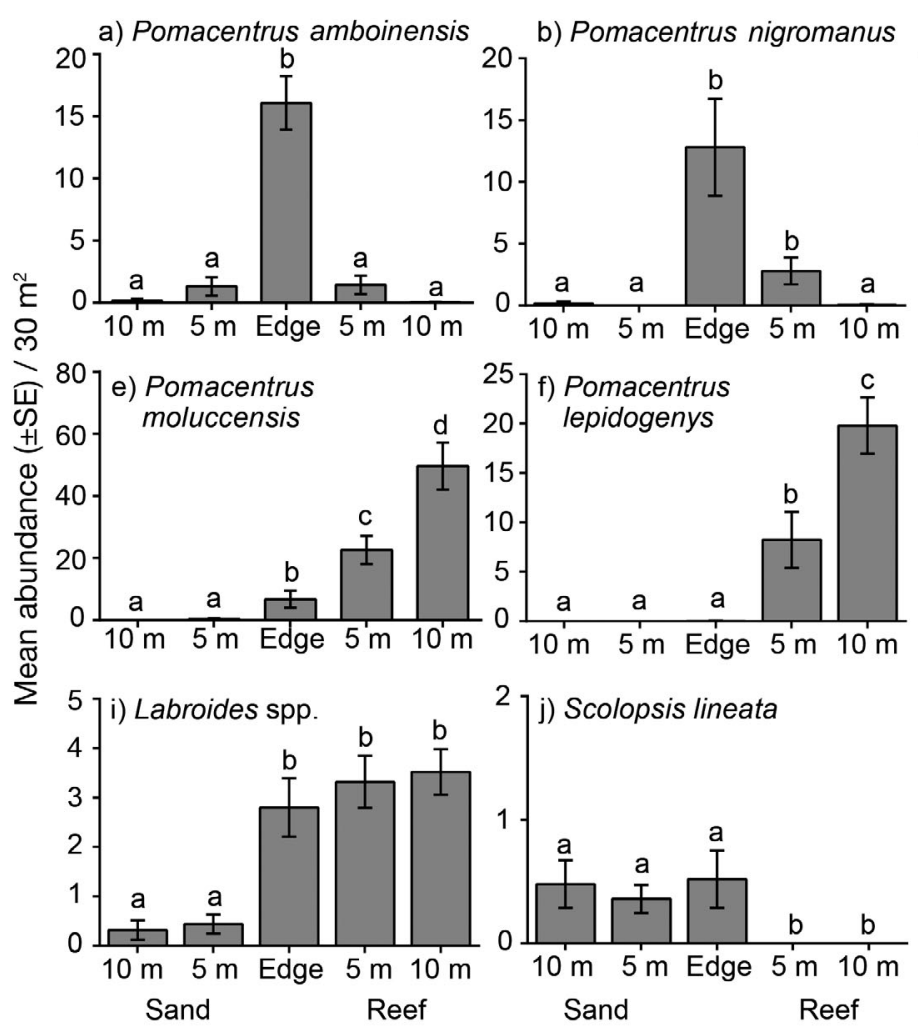

c) Halichoeres melanurus

d) Scolopsis ciliata
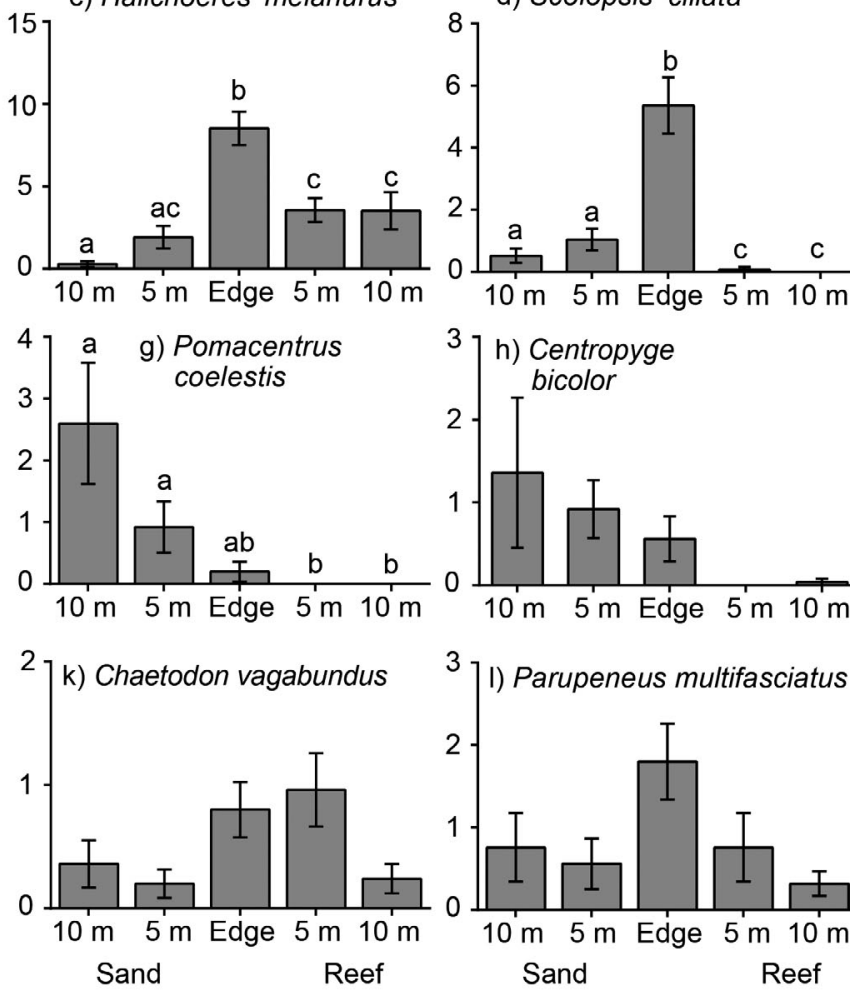

Fig. 4. Mean abundance $( \pm \mathrm{SE})$ of individual species in relation to the edge habitat. Species in (a-d) show positive edge responses, (e-h) show negative edge responses with abundance lower towards the edge from one habitat type, and (i-l) exhibit a neutral edge response. Letters above bars denote similar groups based on post hoc tests interpreted with Bonferroni-corrected p-values

only $5 \mathrm{~m}$ away into the reef or sand (Fig. 4a). Similarly, the bream $S$. ciliata was at least 5 times more abundant along the edge, compared to $5 \mathrm{~m}$ from the edge into the reef or sand habitats (Fig. 4d). These strongly edge-positive species spanned 6 families and included both small-bodied (Chrysiptera rollandi, P. nigromanus, P. amboinensis, H. melanurus, and Halichoeres hortulanus) and larger-bodied (S. ciliata, Scolopsis bilineata, Parupeneus barberinus, Parupeneus multifasciatus, Upeneus tragula, Monotaxis grandoculis, and Lutjanus gibbus) members of the coral reef fish community.

In contrast, 12 of the 51 species (24\%) surveyed appeared to respond negatively to the presence of an edge, with mean abundance higher 5 or $10 \mathrm{~m}$ into either the reef or sand compared to the edge (Fig. $4 \mathrm{e}-\mathrm{h}$ ). For 10 of these species (i.e. $20 \%$ of the community), abundance was significantly lower along the edge compared to only 5 or $10 \mathrm{~m}$ into the reef. For example, abundance of the damselfish $P$. moluccensis was lowest along the edge but increased gradually into the reef habitat, with more than 3 and 7 times greater abundance at 5 and $10 \mathrm{~m}$ from the edge respectively (Fig. 4e). There were also
2 fish species with negative edge responses that were primarily associated with the sand habitat (i.e. $P$. coelestis, Centropyge bicolor), with mean abundance of the angelfish C. bicolor reduced by $\sim 50 \%$ along the edge compared to $10 \mathrm{~m}$ into the sand (Fig. $4 \mathrm{~h}$ ). It should be noted that $P$. coelestis and $C$. bicolor were only observed on sand when there were small coral bommies along the transect. Once again, fish species that exhibited negative edge responses spanned multiple families and included both small-bodied (A. Curacao, Chromis margaritifer, Neoglyphidodon nigroris, Neopomacentrus azysron, $P$. lepidogenys, and $P$. moluccensis) and large-bodied (Zebrasoma scopas, Chaetodon lunulatus, Heniochus varius, and Paracirrhites forsteri) members of the reef fish community.

Of the remaining species, $39 \%$ (20 out of 51) showed no clear response to the presence of the edge. Instead, these species appeared to fall into 1 of 3 distribution patterns. Species were either evenly distributed between the edge and reef habitat, but absent or present in low numbers in sand (e.g. Labroides spp.; Fig. 4i); or they were equally distributed between the edge and sand habitat, but absent or rarely observed on the reef (e.g. S. lineata; Fig. 4j). 
Finally, a few species were observed across all 5 locations with no clear distribution pattern (e.g. Chaetodon vagabundus; Fig. 4k).

\section{Adult and juvenile distribution with distance from edge}

Ontogenetic stage influenced distribution across the edge for both $H$. melanurus $\left(\chi^{2}=32.762, \mathrm{p}<\right.$ $0.001)$ and Thalassoma lunare $\left(\chi^{2}=17.246, \mathrm{p}=\right.$ 0.002). For $H$. melanurus, $57 \%$ of juveniles were observed along edge habitat, compared to $31 \%$ of adults. Inspection of standardised residuals indicated that juveniles were more concentrated along the edge, whereas adults were more evenly distributed across edge and reef transects (Fig. 5a). For T. lunare, adults were more concentrated along the edge than would be expected by chance (Fig. 5b). Almost twothirds of $T$. lunare adults occupied edge habitat, whereas juvenile $T$. lunare were more uniformly spread between the edge and reef locations.

\section{DISCUSSION}

This study is the first to describe the distribution patterns of coral reef fishes in relation to a coral reefsand habitat edge. Overall, $61 \%$ of the 51 fish species appeared to respond to edge habitat, and of these, 22 species $(43 \%)$ were significantly lower or higher in abundance along the edge. Twelve species had positive edge responses with abundance highest along the edge, and 10 species exhibited a negative edge response with abundance lower along the edge com-

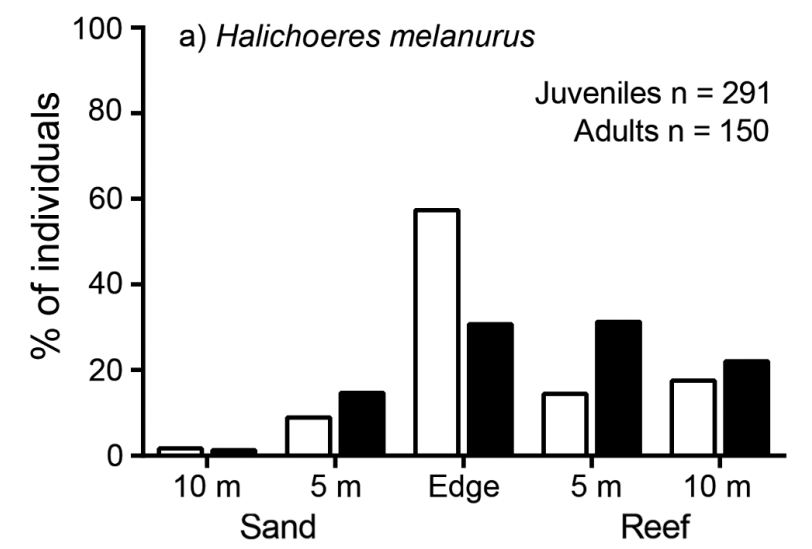

pared to either the reef or sand habitat. The ubiquity of strong edge responses observed in this study suggests that edge effects are prevalent on coral reefs and that edges should be distinguished when looking at processes structuring coral reef fish communities.

Not only did individual fish species respond to the presence of the edge, the composition of the coral reef fish community changed within only 5 to $10 \mathrm{~m}$ of the edge into both sand and reef habitats. The small spatial scale over which edge responses were detected has not been shown before for fishes in coastal marine seascapes. Of the few studies that have examined fish communities along habitat edges, the spatial scales used to measure edge effects have been much larger than in the present study (e.g. 10s to 100 s of $\mathrm{m}$ from the edge; Dorenbosch et al. 2005, Schultz et al. 2012, Smith et al. 2012). For example, Schultz et al. (2012) examined fish assemblages on sedimentary habitat away from rocky reefs with measurements taken at 25-400 m. Here, edge-related distribution patterns within $10 \mathrm{~m}$ were observed across a range of families irrespective of body size, mobility, or feeding ecology, highlighting the need to apply appropriate scales to the study of edge effects. Two further patterns were also revealed that were only detected because multiple measurements were taken away from the edge into each habitat type. First, the reef fish community became increasingly dissimilar with distance from the habitat edge, suggesting a gradient of change rather than an abrupt transition. Secondly, some species (e.g. Chromis atripes, Paracirrhites forsteri) were most abundant $5 \mathrm{~m}$ away from the edge into the reef, rather than either at the edge or $10 \mathrm{~m}$ locations. This finding suggests that fine-scale changes in edge-related distribution

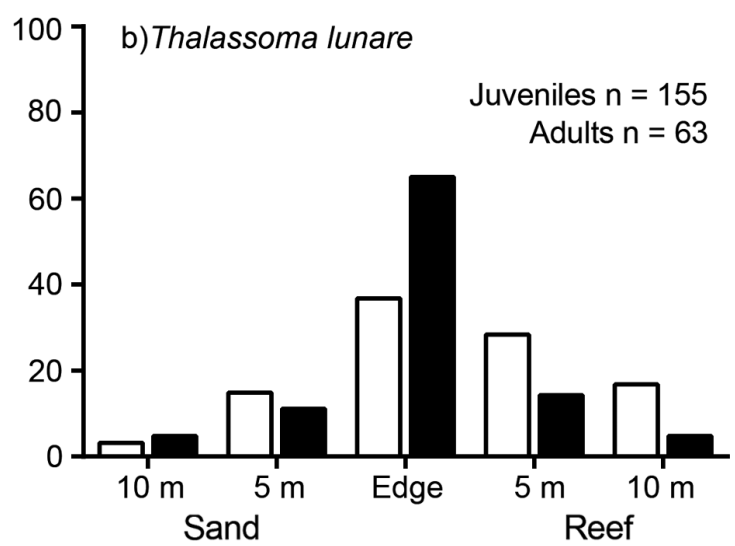

Fig. 5. Percent abundance of adults (black bars) and juveniles (white bars) of 2 reef fish species with distance from the edge habitat. Ontogenetic stage appeared to influence edge-related distribution patterns. (a) Juvenile Halichoeres melanurus were more concentrated along the edge, whereas adults were more evenly distributed between the edge and reef habitat. (b) Adult Thalassoma lunare were more concentrated along the edge, whereas juveniles were more uniformly distributed between the edge and $5 \mathrm{~m}$ into the reef 
patterns may be obscured by sampling designs that only compare edge versus core habitats. Hence we advocate the use of spatially relevant measurements at multiple distances from the edge when exploring the mechanisms underlying edge effects.

Almost half of the fish species in this study were significantly more (e.g. positive edge response) or less (e.g. negative edge response) abundant along the coral reef-sand edge. Ries et al. (2004) proposed 4 main drivers of edge-related distribution patterns: access to spatially separated resources, movement of organisms and materials between adjoining habitat types, mapping on to resources such as food availability and habitat quality, and species interactions (e.g. competition, predation). Here, species-specific edge responses were observed between the edge and reef habitat despite relatively little difference in benthic cover or composition across these locations, raising interesting questions about what is driving these strong response patterns. For example, the corallivore Chaetodon lunulatus was most abundant $10 \mathrm{~m}$ into the reef and rarely observed along the edge (negative edge response), yet in contrast, the congeneric Chaetodon baronessa was evenly distributed between the edge and reef (neutral edge response). Fish species richness also differed between the edge and adjoining habitats. Species richness was consistently highest along the reef edge. This pattern corresponds with findings from the literature on terrestrial edge effects, where higher species diversity is commonly associated with habitat edges (e.g. Ewers \& Didham 2006). Experimental approaches that examine fitness metrics (e.g. survival, recruitment) as well as the strength of species interactions (e.g. competition, predation) across edge gradients will help to tease out the underlying mechanisms driving these edge responses.

Edge-related distribution patterns appear to be, at least partially, influenced by feeding ecology. Carnivores and omnivores were much more frequently observed along the edge than in sand or reef habitat. Our findings are comparable with other edge effects studies in terrestrial and marine environments, where predators are often associated with edge habitat (e.g. Bologna \& Heck 1999, Fagan et al. 1999, Vanderklift et al. 2007, Gorman et al. 2009, Smith et al. 2011). Carnivores and omnivores could be more abundant along reef edges if food availability is higher along edge habitat (Andrén 1995). For example, common prey items for fish, such as crustaceans, polychaetes, and nematodes, have been recorded in higher abundances along the edge of seagrass beds compared to patch interiors (Bowden et al. 2001, Bologna \& Heck
2002, Tanner 2005), and the same may be true of coral reef habitat edges. An alternative, but not mutually exclusive, explanation for the positive edge effects observed among these feeding guilds is that the edge may provide an optimal location from which to access spatially separated resources (Ries et al. 2004). This may be particularly relevant for coral reefs, where many carnivorous coral reef fishes are known to feed on invertebrates in adjacent soft-sediment habitats (Jones et al. 1991). Whilst herbivores appeared unaffected by edge habitat in the present study, their response may differ depending on the type of edge under investigation. For example, the presence of sand halos between coral reefs and seagrass meadows has been attributed to herbivory by reef-associated fishes that use the reef for shelter, and move short distances away from the reef to feed (Ogden \& Zieman 1977, Madin et al. 2011).

In contrast, planktivores generally exhibited negative edge responses and were most abundant into the reef and away from the edge. This finding contrasts with observations from seagrass beds, where planktivorous fishes appear to be more abundant along edge habitat (e.g. Bologna \& Heck 2002, Jelbart et al. 2006, Macreadie et al. 2010). In seagrass beds, edges are considered absorptive boundaries (Strayer et al. 2003). Water flow can be rapidly attenuated upon reaching the seagrass boundary (Gambi et al. 1990, Peterson et al. 2004), and as a consequence, deposition rates of passively transported particles (e.g. algae, plankton, invertebrate larvae) can be enhanced along edge habitat (Bologna \& Heck 2002, Bologna 2006, Carroll et al. 2012). Edges can therefore be preferential habitat in terms of prey availability for planktivorous fishes associated with seagrass beds. However, on coral reefs, edges may not act as absorptive boundaries because the depth profile on a reef is typically greater than that of a seagrass bed. As a result, passively transported particles may be less affected by the reef edge and instead be delivered more uniformly across the reef slope, which would diminish the potential for plankton to accumulate along reef edges. If that assumption is accurate, then it might be expected that planktivores would show no edgerelated distribution patterns if their edge response was driven primarily by the distribution of their food resources. However, the strong negative edge effects we observed among planktivores, combined with the positive edge effects observed among their predators, suggests that both feeding ecology and species interactions contribute to edge-related distribution patterns on coral reefs. 
Ontogenetic stage may also influence edge-related distribution patterns. Here, the distribution of adults and juveniles from 2 species of wrasse were examined. Halichoeres melanurus juveniles were more concentrated along edge habitat, whereas adults were uniformly distributed between the edge and reef locations. In contrast, adults of Thalassoma lunare were more abundant along the edge, whereas juveniles were equally distributed between the edge and $5 \mathrm{~m}$ into the reef. Ontogenetic shifts in habitat use have been documented for several coral reef fishes, and edge-related ontogenetic shifts in fish have been observed in seagrass beds (Nagelkerken et al. 2002, Dorenbosch et al. 2005, Adams et al. 2006, Smith et al. 2011). For example, Smith et al. (2011) observed higher numbers of juvenile King George whiting Sillaginodes punctatus in seagrass bed interiors than adults, which were more abundant on sand adjacent to seagrass. Juveniles may occupy different habitats or within-patch locations compared to adults in order to avoid predators (Shibuno et al. 2008, Grol et al. 2011), to reduce intraspecific competition (Sweatman \& Robertson 1994, Bay et al. 2001), or because they have different resource requirements (Kimirei et al. 2011). Here, although adults and juveniles of each species of wrasse occupied similar habitat (i.e. habitat with reef structure), the subtle spatial differences in distribution patterns indicate that reproductive behaviour by adults, active habitat selection by juveniles, or differential post-settlement mortality processes could be operating to drive edgerelated ontogenetic differences in distribution. Furthermore, the different patterns of distribution of these 2 species of wrasse suggest that adult and juvenile edge responses will be species-specific.

This study is the first to explore whether coral reef fishes respond to a coral reef-sand habitat edge. Edge responses were common, with almost half of the 51 fish species exhibiting either a positive or negative response to edge habitat. Furthermore, these effects were detected within $10 \mathrm{~m}$ of the edge, and did not appear to be driven by habitat structure. These findings suggest that habitat edges may play an important, but overlooked role, in structuring coral reef fish communities. As the first study to examine edge effects between coral reef and sand habitats, it raises many interesting questions about why coral reef fishes respond to edge habitat. In particular, how might increasingly fragmented reefs, which are likely to increase the amount of edge habitat, affect reef fish communities? Here, an observational approach was an important first step in identifying edge-related distribution patterns. Future research should focus on experimental approaches that will enable us to identify the underlying mechanisms driving edge responses.

Acknowledgements. We thank the staff at the Nago Island Mariculture and Research Facility, Kavieng, Papua New Guinea for their local knowledge and field assistance, as well as A. Douglas for help in the field. This project was supported by an Australian Research Council Discovery Grant DP14001800 to G.P.J.

\section{LITERATURE CITED}

Adams AJ, Dahlgren CP, Kellison GT, Kendall MS and others (2006) Nursery function of tropical back-reef systems. Mar Ecol Prog Ser 318:287-301

Airoldi L, Beck MW (2007) Loss, status and trends for coastal marine habitats of Europe. Oceanogr Mar Biol Annu Rev 45:345-405

Andrén H (1995) Effects of landscape composition on predation rates at habitat edges. In: Hansson L, Fahrig L, Merriam G (eds) Mosaic landscapes and ecological processes. Springer, Dordrecht, p 225-255

Andrén H, Angelstam P (1988) Elevated predation rates as an edge effect in habitat islands: experimental evidence. Ecology 69:544-547

Bay LK, Jones GP, McCormick MI (2001) Habitat selection and aggression as determinants of spatial segregation among damselfish on a coral reef. Coral Reefs 20:289-298

Bologna PAX (2006) Assessing within habitat variability in plant demography, faunal density, and secondary production in an eelgrass (Zostera marina L.) bed. J Exp Mar Biol Ecol 329:122-134

Bologna PAX, Heck KL Jr (1999) Differential predation and growth rates of bay scallops within a seagrass habitat. J Exp Mar Biol Ecol 239:299-314

Bologna PAX, Heck KL Jr (2002) Impact of habitat edges on density and secondary production of seagrass-associated fauna. Estuaries 25:1033-1044

* Boström C, Jackson EL, Simenstad CA (2006) Seagrass landscapes and their effects on associated fauna: a review. Estuar Coast Shelf Sci 68:383-403

* Boström C, Pittman SJ, Simenstad C, Kneib RT (2011) Seascape ecology of coastal biogenic habitats: advances, gaps, and challenges. Mar Ecol Prog Ser 427:191-217

* Bowden DA, Rowden AA, Attrill MJ (2001) Effect of patch size and in-patch location on the infaunal macroinvertebrate assemblages of Zostera marina seagrass beds. J Exp Mar Biol Ecol 259:133-154

Cadenasso ML, Pickett ST (2001) Effect of edge structure on the flux of species into forest interiors. Conserv Biol 15: 91-97

* Carroll JM, Furman BT, Tettelbach ST, Peterson BJ (2012) Balancing the edge effects budget: bay scallop settlement and loss along a seagrass edge. Ecology 93:1637-1647

Clarke KR (1993) Non-parametric multivariate analyses of changes in community structure. Aust J Ecol 18:117-143

Clarke KR, Warwick RM (2001) Changes in marine communities: an approach to statistical analysis and interpretation. Primer-E, Plymouth

Connolly RM, Hindell JS (2006) Review of nekton patterns and ecological processes in seagrass landscapes. Estuar Coast Shelf Sci 68:433-444 
Cushman SA (2006) Effects of habitat loss and fragmentation on amphibians: a review and prospectus. Biol Conserv 128:231-240

* Davis JP, Pitt KA, Fry B, Olds AD, Connolly RM (2014) Seascape-scale trophic links for fish on inshore coral reefs. Coral Reefs 33:897-907

Didham RK, Lawton JH (1999) Edge structure determines the magnitude of changes in microclimate and vegetation structure in tropical forest fragments. Biotropica 31: $17-30$

Donovan TM, Jones PW, Annand EM, Thompson FR III (1997) Variation in local-scale edge effects: mechanisms and landscape context. Ecology 78:2064-2075

* Dorenbosch M, Grol MGG, Nagelkerken I, van der Velde G (2005) Distribution of coral reef fishes along a coral reefseagrass gradient: edge effects and habitat segregation. Mar Ecol Prog Ser 299:277-288

Eggleston DB, Etherington LL, Elis WE (1998) Organism response to habitat patchiness: species and habitatdependent recruitment of decapod crustaceans. J Exp Mar Biol Ecol 223:111-132

* Ewers RM, Didham RK (2006) Confounding factors in the detection of species responses to habitat fragmentation. Biol Rev Camb Philos Soc 81:117-142

Fagan WF, Cantrell RS, Cosner C (1999) How habitat edges change species interactions. Am Nat 153:165-182

* Fletcher RJ, Ries L, Battin J, Chalfoun AD (2007) The role of habitat area and edge in fragmented landscapes: definitively distinct or inevitably intertwined. Can J Zool 85: 1017-1030

Gambi MC, Nowell AR, Jumars PA (1990) Flume observations on flow dynamics in Zostera marina (eelgrass) beds. Mar Ecol Prog Ser 61:159-169

Gaston KJ (2000) Global patterns in biodiversity. Nature 405:220-227

*Gates JE, Gysel LW (1978) Avian nest dispersion and fledging success in field-forest ecotones. Ecology 59:871-883

*Gorman AM, Gregory RS, Schneider DC (2009) Eelgrass patch size and proximity to the patch edge affect predation risk of recently settled age 0 cod (Gadus). J Exp Mar Biol Ecol 371:1-9

* Gray JS (1997) Marine biodiversity: patterns, threats and conservation needs. Biodivers Conserv 6:153-175

*Gol MGG, Nagelkerken I, Bosch N, Meesters EH (2011) Preference of early juveniles of a coral reef fish for distinct lagoonal microhabitats is not related to common measures of structural complexity. Mar Ecol Prog Ser 432:221-233

Haddad NM, Brudvig LA, Clobert J, Davies KF and others (2015) Habitat fragmentation and its lasting impact on Earth's ecosystems. Sci Adv 1:e1500052

Harrison S, Bruna E (1999) Habitat fragmentation and largescale conservation: what do we know for sure? Ecography 22:225-232

* Hovel KA, Lipcius RN (2001) Habitat fragmentation in a seagrass landscape: patch size and complexity control blue crab survival. Ecology 82:1814-1829

Hylander K (2005) Aspect modifies the magnitude of edge effects on bryophyte growth in boreal forests. J Appl Ecol 42:518-525

Jelbart JE, Ross PM, Connolly RM (2006) Edge effects and patch size in seagrass landscapes: an experimental test using fish. Mar Ecol Prog Ser 319:93-102

Jones GP, Ferrell DJ, Sale PF (1991) Fish predation and its impact on the invertebrates of coral reefs and adjacent sediments. In: Sale PF (ed) The ecology of fishes on coral reefs. Academic Press, San Diego, CA, p 156-179

*Kimirei IA, Nagelkerken I, Griffioen B, Wagner C, Mgaya YD (2011) Ontogenetic habitat use by mangrove/seagrass-associated coral reef fishes shows flexibility in time and space. Estuar Coast Shelf Sci 92:47-58

Krebs CJ (2006) Ecology after 100 years: progress and pseudo-progress. N Z J Ecol 30:3-11

* Langlois TJ, Anderson MJ, Babcock RC (2005) Reef-associated predators influence adjacent soft-sediment communities. Ecology 86:1508-1519

* Langlois TJ, Anderson MJ, Babcock RC (2006) Inconsistent effects of reefs on different size classes of macrofauna in adjacent sand habitats. J Exp Mar Biol Ecol 334:269-282

* Laurance WF, Yensen E (1991) Predicting the impacts of edge effects in fragmented habitats. Biol Conserv 55:77-92

* Laurance WF, Nascimento HEM, Laurance SG, Andrade A and others (2007) Habitat fragmentation, variable edge effects, and the landscape-divergence hypothesis. PLOS ONE 2:e1017

*Maciá S, Robinson MP (2005) Effects of habitat heterogeneity in seagrass beds on grazing patterns of parrotfishes. Mar Ecol Prog Ser 303:113-121

Macreadie PI, Hindell JS, Keough MJ, Jenkins GP, Connolly RM (2010) Resource distribution influences positive edge effects in a seagrass fish. Ecology 91:2013-2021

*Madin EMP, Madin JS, Booth DJ (2011) Landscape of fear visible from space. Sci Rep 1:14

Murcia C (1995) Edge effects in fragmented forests: implications for conservation. Trends Ecol Evol 10:58-62

Nagelkerken I, Roberts CM, van der Velde G, Dorenbosch M, van Riel MC, Cocheret de la Moriniére E, Nienhuis PH (2002) How important are mangroves and seagrass beds for coral-reef fish? The nursery hypothesis tested on an island scale. Mar Ecol Prog Ser 244:299-305

Ogden JC, Zieman JC (1977) Ecological aspects of coral reef-seagrass bed contacts in the Caribbean. Proc 3rd Int Coral Reef Symp, Miami 1:377-382

* Orth RJ, Carruthers TJB, Dennison WC, Duarte CM and others (2006) A global crisis for seagrass ecosystems. Bioscience 56:987-996

Peterson CH, Luettich RA Jr, Micheli F, Skilleter GA (2004) Attenuation of water flow inside seagrass canopies of differing structure. Mar Ecol Prog Ser 268:81-92

* Ries L, Fletcher RJ Jr, Battin J, Sisk TD (2004) Ecological responses to habitat edges: mechanisms, models, and variability explained. Annu Rev Ecol Evol Syst 35:491-522

Saunders DA, Hobbs RJ, Margules CR (1991) Biological consequences of ecosystem fragmentation: a review. Conserv Biol 5:18-32

Schultz AL, Malcolm HA, Bucher DJ, Smith SDA (2012) Effects of reef proximity on the structure of fish assemblages of unconsolidated substrata. PLOS ONE 7:e49437

* Shibuno T, Nakamura Y, Horinouchi M, Sano M (2008) Habitat use patterns of fishes across the mangrove-seagrass-coral reef seascape at Ishigaki Island, southern Japan. Ichthyol Res 55:218-237

Shulman MJ (1985) Recruitment of coral reef fishes: effects of distribution of predators and shelter. Ecology 66: 1056-1066

Smith TM, Hindell JS, Jenkins GP, Connolly RM (2008) Edge effects on fish associated with seagrass and sand patches. Mar Ecol Prog Ser 359:203-213

* Smith TM, Hindell JS, Jenkins GP, Connolly RM, Keough MJ (2011) Edge effects in patchy seagrass landscapes: 
the role of predation in determining fish distribution. J Exp Mar Biol Ecol 399:8-16

Smith TM, Jenkins GP, Hutchinson N (2012) Seagrass edge effects on fish assemblages in deep and shallow habitats. Estuar Coast Shelf Sci 115:291-299

Strayer DL, Power ME, Fagan WF, Pickett STA, Belnap J (2003) A classification of ecological boundaries. Bioscience 53:723-729

Sweatman H, Robertson DR (1994) Grazing halos and predation on juvenile Caribbean surgeonfishes. Mar Ecol

Editorial responsibility: Romuald Lipcius,

Gloucester Point, Virginia, USA
Prog Ser 111:1-6

Tanner JE (2005) Edge effects on fauna in fragmented seagrass meadows. Austral Ecol 30:210-218

* Turner MG (2005) Landscape ecology: What is the state of the science? Annu Rev Ecol Evol Syst 36:319-344

*Vanderklift MA, How J, Wernberg T, MacArthur LD, Heck KL Jr, Valentine JF (2007) Proximity to reef influences density of small predatory fishes, while type of seagrass influences intensity of their predation on crabs. Mar Ecol Prog Ser 340:235-243

Submitted: June 15, 2016; Accepted: October 14, 2016 Proofs received from author(s): November 24, 2016 